\title{
WITNESS PROTECTION MEASURES AT THE INTERNATIONAL CRIMINAL COURT: LEGAL FRAMEWORK AND EMERGING PRACTICE
}

\begin{abstract}
In the first years of its existence, the issue of protective measures for witnesses has developed into one of the core issues for the International Criminal Court (ICC). Despite its obvious relevance, academic discussions have so far largely ignored this aspect of the Court's work. This article will argue that, in contrast to the ad hoc Tribunals, the Rome Statute and the Rules of Procedure and Evidence split responsibilities for protective measures between the different organs of the Court, but they nevertheless fail to adequately define the precise boundaries of these responsibilities. The legal framework has therefore created uncertainty, even confusion as to the practical responsibilities for protective measures within the Court. The article will examine some resulting problems in the early practice of the ICC. At the same time, the article will present established practices in the field of witness protection that have been consensually developed between all organs of the Court. In its conclusion, the article will formulate recommendations as to how the Court can further overcome the issue of inter-organ responsibilities that are shared and divided at the same time. In this context, protective measures for witnesses should be viewed as an example as to how the Court, in its infant years, is in the process of developing a measured and balanced system that transfers statutory responsibilities into practice.
\end{abstract}

\section{INTRODUCTION}

In March 2010, the protection of witnesses was identified as a priority area for the International Criminal Court (ICC or the Court) to

* Office of the Prosecutor, International Criminal Court, M.A. (Hamburg, 1993), Ph.D. (Hamburg, 1997), LL.M. (Leiden, 2011). The views expressed in this article are those of the author alone and do not necessarily reflect the views of the Office of the Prosecutor. 
increase clarity with respect to the roles of its organs. ${ }^{1}$ This article will examine why the protection of witnesses has become an important issue for assessing the efficiency of the ICC. What guidance does the statutory framework of the Court provide on the role of the organs, and how has the jurisprudence developed in that regard? What practical problems in relation to protective measures have occurred in the early work of the Court, and how have they been solved?

Protective measures have become an essential issue in the early practice of the ICC because most evidence presented during ICC proceedings has taken the form of witness testimony. Related of course is the fact that the ICC conducts investigations and prosecutions in situations of ongoing conflict or immediate post-conflict, which increases the demands on the Court's witness protection capacities. Importantly, the legal framework at the ICC, in contrast to the International Criminal Tribunal for the former Yugoslavia (ICTY), the International Criminal Tribunal for Rwanda (ICTR) and the Special Court for Sierra Leone (SCSL), splits responsibilities between the different organs of the Court, therefore creating uncertainty, even confusion as to the practical responsibilities within the Court.

While there is no lack of academic attention for the work of the Court, scholarly contributions have so far largely ignored the aspect of the Court's work dealing with protective measures. If covered, legal literature has focused on specific aspects of protective measures at the ICC, i.e. the relationship between anonymous witness testimony and protective measures ${ }^{2}$; or a comparison of judicial protective measures between the different international criminal tribunals. ${ }^{3}$ Some publications have described the work of the Court's Registry, including its efforts in relation to witness protection. ${ }^{4}$

${ }^{1}$ ICC Assembly of States Parties, Committee on Budget and Finance, Report of the Court on Measures to Increase Clarity on the Responsibilities of Different Organs, ICC-ASP/9/CFB.1/12, 18 March 2010.

${ }^{2}$ M. Kurth, 'Anonymous Witnesses Before the International Criminal Court: Due Process in Dire Straits', in C. Stahn and G. Sluiter (eds.), The Emerging Practice of the International Criminal Court (Leiden, Boston, Martinus Nijhoff Publishers, 2009) 615.

${ }^{3}$ C. McLaughlin, 'Victim and Witness Measures of the International Criminal Court: A Comparative Analysis' (2007) 6 The Law and Practice of International Courts and Tribunals 189.

${ }^{4}$ S. Arbia, 'The International Criminal Court: Witness and Victim Protection and Support, Legal Aid and Family Visits' (2010) 36 Commonwealth Law Bulletin 519; M. Dubuisson, A. Bertrand and N. Schauder, 'Contribution of the Registry to Greater Respect for the Principles of Fairness and Expeditious Proceedings before the International Criminal Court', in Stahn and Sluiter (n.2), 565-584 
A comprehensive study has focused on the protection of witnesses in the African context, including a chapter on the ICC. ${ }^{5}$

In contrast to these previous approaches, this article will view protective measures primarily as an example of the ICC, in its infant years, transfers statutory responsibilities into the practical work of the Court. The article suggests implementing a model that emphasizes a comprehensive inter-organ approach towards protective measures while defining lead responsibilities for specific court organs at the same time. The model is inherent in the current practice of the Court and can in part be distilled from the existing jurisprudence. By identifying and promoting the model, the article intends to contribute to ongoing efforts to achieve a better governance of the Court. ${ }^{6}$

The paper will first analyze the various provisions in the Rome Statute and Rules of the ICC dealing with protective measures. While Article 68(1) of the Rome Statute assigns responsibility for witness protection to the Court as a whole, the Pre-Trial Chamber and Trial Chamber (2.1), the Prosecutor (2.2) and the Registrar (2.3) are all assigned with further specific responsibilities in relation to protective measures. An analysis of the travaux préparatoires of the Rome Statute and the Rules in relation to relevant provisions will be undertaken in order to clarify some of the ambiguities inherent in the current drafting (2.4). In Section III, the paper will closely examine two case studies that reflect the inherent tensions between Article 43(6) and Article 68(1) of the Rome Statute. In 2008, the ambiguities of the drafting led to practical problems in the Lubanga proceedings. As a result, the disclosure of identity of the witnesses got delayed, which in turn led to one of several postponements in the proceedings (3.1). In the same year, the need for clarification also arose in the Katanga proceedings over the question of "preventive relocation" (3.2).

Subsequently, the paper will present agreed practices for protective measures of the Court that have consensually been developed between the different organs within the first few years of the Court's existence (Section IV). These established practices illustrate the dedicated efforts of all Court organs to overcome the difficulties of

\footnotetext{
${ }^{5}$ C. Mahony, The Justice Sector Afterthought: Witness Protection in Africa (Pretoria, Institute for Security Studies, 2010) especially 15-58.

${ }^{6}$ A more in-depth discussion of this problem will be provided in the conclusion of this paper.
} 
the early days of the Court. The focus of the section will be on nonjudicial protective measures. The practices include: an Initial Response System (IRS) (4.1); a Security Risk Assessment (SRA) and an Individual Risk Assessment (IRA) (4.2); and the Court's Witness Protection Programme (ICCPP) (4.3).

In the conclusion (Section V), the paper provides a short summary of its legal analysis and outlines the above-mentioned model of a comprehensive inter-organ approach and phased lead responsibilities. It recommends implementing the model in the framework of other ongoing efforts to achieve better efficiency within the Court.

\subsection{Scope}

As protective measures at the ICC offer a wide range of potential subtopics, it is deemed necessary to determine what this article will not deal with. In this regard, three important limitations need to be explicitly made.

First, the focus of this paper will be on protective measures for witnesses, not victims, although the Rome Statute and the Rules often refer to the protection of both groups at the same time. For the purpose of this paper, a witness is identified as an individual who has provided a formal statement to be used in the proceedings of the Court. ${ }^{7}$ Victims are defined in Rule 85 as "natural persons who have suffered harm as a result of the commission of any crime within the jurisdiction of the Court". At times, a victim can also be a witness. In relation to the protection obligation of the Court, it is argued that, in this particular case, the witness status prevails, as it guarantees a more comprehensive obligation of protection towards the individual. It will become evident throughout this article that the Court already struggles to cope with its protection obligations towards the more limited group of individuals intended to be called as witnesses in court proceedings. This paper therefore argues that protection obligations to victims should be construed rather narrowly.

Secondly, and related to the issue of victims' protection, is the question of which individuals might benefit from the Court's pro-

\footnotetext{
${ }^{7}$ It has been pointed out that, "for protection purposes, it is the function of the witness - as a person in possession of information important to the judicial or criminal proceedings - that is relevant rather than his or her status or the form of testimony". See United Nations Office on Drugs and Crime, Good Practices for the Protection of Witnesses in Criminal Proceedings Involving Organized Crime (2008) 18.
} 
tection obligation. The Appeals Chamber has determined that this obligation extends to "all persons at risk by the investigation of the Prosecutor". ${ }^{8}$ It seems to be accepted that the obligation extends to intermediaries and ICC staff in the field, but the precise scope of the protection obligation is far from being settled and will stay outside of the scope this paper. ${ }^{9}$ Thus far, protective measures for intermediaries appear to be limited to redacting relevant portions of statements or documents and to not reveal the identity of an intermediary to the defence or the public. ${ }^{10}$

Thirdly, while the paper designs a model for protection responsibilities throughout the whole life span of a court case at the ICC, the in-depth analysis focuses on the time period prior to the in-court testimony of a witness. The implementation of protective measures during and after in-court testimony will be dealt with in a summarized manner.

\section{LEGAL FRAMEWORK}

The statutory framework of the ICC is significantly different from the ad hoc Tribunals, as it distributes responsibility for witness protection between the different organs of the Court. There is no equivalent for these elaborate provisions in the Statutes or Rules of the ICTY, ICTR or SCSL. The provisions reflect the importance attributed to the protection of witnesses in the Statute. However, the statutory framework leaves the Court ambiguous as to their practical implementation.

\footnotetext{
${ }^{8}$ Prosecutor v. Katanga and Ngudjolo (Judgement on the Appeal of the Prosecutor Against the Decision of Pre-Trial Chamber I, entitled, 'First Decision on the Prosecution Request for Authorisation to Redact Witness Statements') ICC-01/04-01/ 07-475 (13 May 2008), para. 44.

${ }^{9}$ For an introduction into the discussion, see International Bar Association, 'The ICC's Trials: An Examination of Key Judicial Developments at the International Criminal Court Between November 2009 and April 2010' (May 2010) 27.

${ }^{10}$ Having realized the need to clarify its policy towards intermediaries, in 2010, the Court has drafted and circulated 'Draft Guidelines governing the relations between the Court and Intermediaries'. The document does not only provide a definition of the fluid term of intermediaries, but also acknowledges the Court's obligation towards the protection of intermediaries. See Victims' Rights Working Group, 'Intermediaries' guidelines: Outstanding issues' (April 2011), 2-4.
} 
Similar to the general references in the ICTY and ICTR Statutes, ${ }^{11}$ Article 68(1) of the Rome Statute assigns responsibility for witness protection to the Court as a whole:

The Court shall take appropriate measures to protect the safety, physical and psychological well-being, dignity and privacy of victims and witnesses. In doing so, the Court shall have regard to all relevant factors, including age, gender as defined in article 7, paragraph 3, and health, and the nature of the crime, in particular, but not limited to, where the crime involves sexual or gender violence or violence against children. $^{12}$

\subsection{Chambers}

Three statutory provisions deal specifically with the responsibilities of the Chambers for the protection of witnesses.

According to Article 57(3)(c), the Pre-Trial Chamber may "where necessary, provide for the protection and privacy of victims and witnesses". The reference to witness protection in Article 57 mainly serves the purpose of clarifying the competence of the Chamber to provide applicable measures at the pre-trial stage. ${ }^{13}$ Rule 86 further establishes as a general principle that the Pre-Trial Chamber, in making any decision or order, "shall take into account the needs of all victims and witnesses in accordance with article 68 ".

According to Article 64(2), "the Trial Chamber shall ensure that a trial is fair and expeditious and is conducted with full respect for the rights of the accused and due regard for the protection of victims and witnesses". In essence, the Chamber has to apply a balancing test between the fair trial rights of the accused and the protection of witnesses. ${ }^{14}$ It has been judged that this "will be a difficult balance to

${ }^{11}$ Statute of the International Criminal Tribunal for the former Yugoslavia, updated version September 2009, Article 22; Statute of the International Criminal Tribunal for Rwanda, Article 22.

${ }^{12}$ According to Rome Statute Article 34, the term Court refers to all judicial organs of the ICC (i.e. Presidency, Chambers, Prosecution, and Registry). Other provisions of the Statute further describe the responsibilities of these organs.

${ }^{13}$ F. Guariglia, K. Harris and G. Hochmayr, 'Article 57', in O. Triffterer (ed.), Commentary on the Rome Statute of the International Criminal Court. Observers' Notes, Article by Article (München, Baden-Baden, Nomos, 2008) 1126.

${ }^{14}$ For the treatment of due process rights in the jurisprudence of the ICC, see, more generally: M. Kurth, 'Anonymous Witnesses Before the International Criminal Court: Due process in Dire Straits', in Stahn and Sluiter (n. 2); McLaughlin, 207. 
reach especially for the disclosure to the accused of names and addresses of the witnesses in order to allow preparing their defense". ${ }^{15}$ The rights of the accused are broadly defined in Article 67.

Article 64(6)(e) provides that "in performing its functions prior to trial or during the course of a trial, the Trial Chamber may, as necessary (...) provide for the protection of the accused, witnesses and victims". It has been argued that this provision imposes a duty rather than a discretionary power on the Trial Chamber. ${ }^{16}$ In the same sense, Trial Chamber I has stated that "once constituted, [it had] a statutory responsibility for the protection of victims and witnesses throughout the entirety of the period it is seized of the case". ${ }^{17}$

Following equivalent rules at ICTY and ICTR, ${ }^{18}$ Rule 81(4) and Rule 87 give Chambers the authority to grant judicial measures of witness protection, either related to limitations of disclosure or as in-court protective measures.

\subsection{Prosecutor}

Article 54(3)(f) and Article 68(1) indicate that the Prosecutor takes protective measures, thereby emphasizing that the Prosecutor has a mandate to decide on and implement protective measures in relation to his or her witnesses.

According to Article 54(3)(f), the Prosecutor "may take necessary measures, or request that necessary measures be taken, to ensure the confidentiality of information, the protection of any person or the preservation of evidence". It has been argued that Article 54(3)(f) gives the Prosecutor discretionary power in the area of witness protection and that he or she therefore has a witness protection authority alongside that of the Court and the Victims and Witnesses Unit. ${ }^{19}$

\footnotetext{
${ }^{15}$ G. Bitti, 'Article 64' in Triffterer (n. 13) 1203-1204.

${ }^{16}$ W. A. Schabas, The International Criminal Court. A Commentary on the Rome Statute (Oxford, Oxford University Press, 2010) 768.

${ }^{17}$ Prosecutor v. Lubanga, (Reasons for Oral Decision Lifting the Stay of Proceedings, ICC-01/04-01/06-1644 (23 January 2009), para. 41.

${ }^{18}$ International Criminal Tribunal for the former Yugoslavia, Rules of Procedure and Evidence, IT/32/Rev.45, 8 December 2010, Rules 69 and 75; International Criminal Tribunal for Rwanda, Rules of Procedure and Evidence, adopted on 29 June 2009, Rules 69 and 75.

${ }^{19}$ M. Bergsmo and P. Kruger, 'Article 54', in Triffterer (n. 13) 1086-1087.
} 
The second statutory provision is Article 68(1):

The Court shall take appropriate measures to protect the safety, physical and psychological well-being, dignity and privacy of victims and witnesses. In so doing, the Court shall have regard to all relevant factors, including age, gender as defined in article 7, paragraph 3, and health, and the nature of the crime, in particular, but not limited to, where the crime involves sexual or gender violence or violence against children. The Prosecutor shall take such measures particularly during the investigation and prosecution of such crimes. These measures shall not be prejudicial to or inconsistent with the rights of the accused and a fair and impartial trial. [Emphasis added]

The language of Article 68(1) indicates that it is a mandatory duty of the Prosecutor to take protective measures and that the power of the Prosecutor to take protective measures is not subordinate to that of any other organ of the Court. ${ }^{20}$ The last sentence of paragraph 1 (quoted above) appears to provide a caveat intended to ensure that a decision by the Prosecution to provide protective measures to a witness must be undertaken in an impartial and objective manner. ${ }^{21}$ This rationale is supported by the fact that certain protective measures are provided by the Victim and Witnesses Unit (VWU), so that they should not be construed as an incentive for the witness to provide evidence in favour of the prosecution's case.

\subsubsection{Prosecution's Disclosure Obligation and Exemptions}

Rule 76(1) obliges the Prosecutor to disclose to the defence the identity and the statements of any witnesses he or she intends to call to testify, "sufficiently in advance to enable the adequate preparation of the defence". ${ }^{22}$ This obligation, however, is not absolute. The Prosecutor can request an exemption if the protection of victims

\footnotetext{
${ }^{20}$ Prosecutor v. Katanga and Ngudjolo (Judgement on the Appeal of the Prosecutor Against the "Decision on Evidentiary Scope of the Confirmation Hearing, Preventive Relocation and Disclosure Under Article 67(2) of the Statute and Rule 67 of the Rules" of Pre-Trial Chamber I, Dissenting Opinion of Judge Georghis M. Pikis and Judge Daniel David Ntanda Nsereko), ICC-01/04-01/07-776 (26 November 2008), para. 15.

${ }^{21}$ Mahony (n. 5) 35.

${ }^{22}$ For the drafting history of this rule, see H. Brady, 'Disclosure of Evidence', in R. Lee (ed.), The International Criminal Court: Elements of Crimes and Rules of Procedure and Evidence (Ardsley, New York, Transnational Publishers, 2001) 408-410.
} 
and witnesses is of concern, in accordance with Rules 76(4), 81(4) or 87(3). Article 68(5) further provides for the possibility to submit the summary of a witness statement prior to the commencement of the trial in cases "where the disclosure of evidence or information pursuant to this Statute may lead to the grave endangerment of the security of a witness or his or her family". All these scenarios are exemptions from the general disclosure obligation of the Prosecutor; and they therefore need to be authorized by the Chambers before being implemented.

\subsection{Registrar}

Whereas the Statute is clear that the Prosecutor takes protective measures, the function of the VWU is described two-fold. The unit provides protective measures (Article 43(6) and Rule 17(2)(a)(i)); and it advises on or recommends these measures (Article 68(4) and Rule 17(2)(a)(ii)). The advisory role of the VWU is further emphasized in Rule 87(1) and Rule 88(1).

According to Article 43(6):

"the Registrar shall set up a Victims and Witnesses Unit within the Registry. This Unit shall provide, in consultation with the Office of the Prosecutor (OTP), protective measures and security arrangements, counselling and other appropriate assistance for witnesses, victims who appear before the Court, and others who are at risk on account of testimony given by such witnesses"

Through Article 43(6), the VWU becomes a statutory organ of the Registry, and therefore its budget is part of the Court's regular budget. ${ }^{23}$ As an organ of the Registry, the VWU has only a limited administrative relationship with the Prosecutor, who is, according to Article 42(2), in charge of his or her own administration. ${ }^{24}$ The ICC system differs in this regard from the ICTY and ICTR where the Registry is responsible for the administration of both Chambers and the Office of the Prosecutor.

According to Article 68(4), "the Victims and Witnesses Unit may advise the Prosecutor and the Court on appropriate protective

${ }^{23}$ T. Ingadottir, F. Ngendahayo, and P. Sellers, 'The International Criminal Court. The Victims and Witnesses Unit (Article 43.6 of the Rome Statute). A Discussion Paper' 8 (2000) (ICC Discussion Paper No. 1).

24 "The Prosecutor shall have full autonomy over the management and administration of the Office including the staff, facilities and resources thereof." 
measures, security arrangements, counselling and assistance as referred to in article 43, paragraph 6".

Article 68(4) makes an explicit link to Article 43(6), but the content of both articles are not consistent. Article 68(4) provides that the VWU may advise the Prosecutor and the Court on protective measures. To the contrary, Article 43(6) stipulates that the VWU shall provide, in consultation with the Office of the Prosecutor, protective measures and security arrangements. Read together, these provisions make it difficult to determine who in the end is in charge of implementing protective measures. Neither Article 68(4) nor Article 43(6) provide any further guidance on the protective measures that they refer to.

In its jurisprudence, the Appeals Chamber has concluded that the VWU "is responsible not merely for giving advice on protective measures, but for the actual provision of protective measures and security arrangements", ${ }^{25}$ thereby emphasizing the importance of Article 43(6). The dissenting opinion to the same judgement of Judges Pinkis and Nsereko, however, has come to a different finding, relying primarily on Article 68(4). In their view, "the Victims and Witnesses Unit is intended to provide facilities for the protection of victims and witnesses, and by the expertise it develops, to comfort them in the best possible way, facilitating, in a proper case, the carrying out of the measures of protection deemed necessary by the Prosecutor" ${ }^{26}$ Similar to the dissenting opinion of the Appeals Chamber, it has been argued in legal literature that Article 43(6) must be read in pari materiae with Article 68(4). The role of the VWU with respect to protection measures "must be an advisory one", as it is simply not within the power of the VWU to order protection measures for witnesses, because the VWU does not have the means to issue such orders or to enforce them. ${ }^{27}$

Rule 17(2)(a) further contributes to the existing ambiguity, as the functions of the VWU in relation to witnesses are described as both providing witnesses with adequate protective and security measures and at the same time recommending to the organs of the Court the

${ }^{25}$ Prosecutor v. Katanga and Ngudjolo (Judgement on the Appeal of the Prosecutor Against the "Decision on Evidentiary Scope of the Confirmation Hearing, Preventive Relocation and Disclosure under Article 67(2) of the Statute and Rule 67 of the Rules" of Pre-Trial Chamber I), ICC-01/04-01/07-776 (26 November 2008), para. 89 [hereafter: Appeals Judgement on Preventive Relocation].

${ }^{26}$ Appeals Judgement on Preventive Relocation, Dissenting Opinion of Judge Georghis M. Pikis and Judge Daniel David Ntanda Nsereko (n. 20), paras. 14, 22.

${ }^{27}$ D. Tolbert, 'Article 43', in Triffterer (n. 13) 989. 
adoption of protection measures. In light of the early criticism about the lack of clarity in the Rome Statute, it is somewhat surprising that the Rules, finalized in September 2002, have contributed little to clarify the position of the VWU as created by the Statute. ${ }^{28}$ One could conclude that there was not much awareness of the potential for controversy resulting from the drafting of Article 43(6), Article 68(1) and Rule 17(2)(a). Earlier drafts of Rule 17(2)(a) contain only a reference to the advisory function of the VWU, but do not include a reference to the actual provision of adequate protective and security measures. ${ }^{29}$ It can not be traced precisely when the second function was included into the drafting of Rule 17(2)(a). ${ }^{30}$

The matter is further complicated by different conceptions of the VWU with respect to how the unit is supposed to provide protective measures. One view would consider the VWU as a mere service provider, implementing requests of prosecution and defence, and thereby complementing the authority of the prosecution to request measures in accordance with Article 54(3)(f). Alternatively, one could view the VWU as a statutory organ providing neutral services to both prosecution and defence. In that view, the wording of Article 43(6), asking the VWU to consult solely with the OTP, is ambivalent. In sum, the VWU does not only have the double-function of advising and providing, but the latter function is based on different conceptions of how the unit fits into the overall institutional structure of the Court.

The ambiguities of the drafting of Statute and Rules cannot be solved if one looks solely at the criteria of context, object, and

${ }^{28}$ G. Dive, 'The Registry', in Lee (n. 20) 267. Most of the recommendations in the paper of Ingadottir et al. in the year 2000 about the role of VWU seem to have been ignored when finalizing the Rules of Procedure and Evidence. See T. Ingadottir et al. (n. 23).

${ }^{29}$ Preparatory Commission for the International Criminal Court, Report on the International Seminar on Victims' Access to the International Criminal Court, PCNICC/1999/WGPRE/INF/2 (6 July 1999) at 5.

${ }^{30}$ A Canadian Proposal of July 1999 suggests adding a paragraph to the functions of the unit, so that it assists victims and witnesses in obtaining protective measures. That wording, however, still falls short of providing protective measures. See Preparatory Commission for the International Criminal Court, Canadian Proposal to PCNICC/1999/WGRPE/INF.2 of July 1999 (10 August 1999). In the final coordinating draft of the Rules, discussed at a meeting at Mont Tremblay in May 2000, the reference to VWU both providing and recommending on protective measures is included. See Preparatory Commission on the International Criminal Court, Outcome of the Inter-Sessional meeting held at Mont Tremblay, Canada, from 30 April to 5 May 2000, circulated at the request of Canada, PCNICC/2000/WGRPE/INF/1 (24 May 2000) at 19. 
purpose, as outlined in Article 31(1) of the Vienna Convention on the Law of Treaties. ${ }^{31}$ As a supplementary means of interpretation, in accordance with Article 32 of the Convention, the travaux préparatoires of the Rome Statute will be analyzed in the following section. ${ }^{32}$

\subsection{Travaux Préparatoires Article 43(6) and Article 68(1)}

The International Law Commission (ILC) draft for an ICC, finalized in 1994, resembled, in its brevity on protective measures, the equivalent provisions in the Statutes of ICTY and ICTR. ${ }^{33}$ The Ad Hoc Committee on the Establishment of a Permanent International Criminal Court, established in 1995, considered that "this provision was viewed by a few delegations as calling for further elaboration, particularly with regard to the protection of victims and witnesses". 34 Therefore, the Preparatory Committee on an International Criminal Court, following the Ad Hoc Committee in 1996, recommended separating the protection of victims and witnesses from the protection of the accused. ${ }^{35}$ The Preparatory Committee also made the first

\footnotetext{
31 "Its objects may be gathered from the chapter of the law in which the particular section is included and its purposes from the wider aims of the law as may be gathered from its preamble and general tenor of the treaty". See Situation in the Democratic Republic of Congo (Judgment on the Prosecutor's Application for Extraordinary Review of Pre-Trial Chamber 1's 31 March 2006 Decision Denying Leave to Appeal), ICC-01/04-168 (13 July 2006), para. 33. Following this definition, the purpose of both articles is the same. In relation to the objects, Article 43 is placed in Part IV of the Statute, covering the composition of the Court whereas Article 68 is in Part VI, which covers "The Trial". Ultimately, these criteria do not solve the ambiguities between the two articles.

${ }^{32}$ Article 32, Vienna Convention on the Law of the Treaties, 23 May 1969: "Recourse may be had to supplementary means of interpretation, including the preparatory work of the treaty and the circumstances of its conclusion, in order to confirm the meaning resulting from the application of article 31 , or to determine the meaning when the interpretation according to article 31: (a) leaves the meaning ambiguous or obscure; or (b) leads to a result which is manifestly absurd or unreasonable".

33 'Report of the International Law Commission on the Work of Its Forty-Sixth Session, Draft Statute for an International Criminal Court, 2 May-22 July 1994', G.A., 49th Session, Supp. No. 10, A/49/10, 1994.

34 'Report of the Ad Hoc Committee on the Establishment of an International Criminal Court', G.A., 50th Session, Supp. No. 22, A/51/22, 1995, para. 181.

35 'Report of the Preparatory Committee on the Establishment of an International Criminal Court', Volume 1 (Proceedings of the Preparatory Committee During March-April and August 1996), G.A., 51st Session, Supp. No. 22, A/51/22, 1996, paras. 280-282.
} 
reference to the establishment of a Victims and Witnesses Unit, quoting "proposals, as well as the precedent of the Yugoslav Tribunal, for a witness and victim unit to be established to provide services and support to victims and witnesses, under the supervision of the office of either the Registrar or the Prosecutor". ${ }^{36}$ A July 1996 proposal by Australia and the Netherlands suggested including the unit within the Registry. ${ }^{37}$

Extensive discussions on the issue of witness protection took place at the Fourth Session of the Preparatory Committee in August 1997. ${ }^{38}$ A proposal brought forward by New Zealand at this session for the first time clearly distinguished responsibilities between organs of the Court. ${ }^{39}$ Whereas measures to ensure the safety of victims and witnesses were an obligation to the whole Court, the Prosecutor "shall, in ensuring the effective investigation and prosecution of crimes, respect and take appropriate measures to protect the privacy, integrity and security of victims and witnesses" and "the Victims and Witnesses Unit (...) shall advise the Prosecutor and the Court on appropriate measures of protection and other measures affecting their rights" [emphasis added].

When the Preparatory Committee presented its final draft in April 1998, the question where the Unit was to be placed remained under discussion. ${ }^{40}$ The article dealing with the OTP (draft Article 43) included a provision in square brackets that "the Office of the Prosecutor shall be responsible for providing protective measures to witnesses to be called by the Prosecution", whereas draft Article 44 asked the Registry to set up a VWU.

\footnotetext{
${ }^{36}$ Ibid., para. 281 [emphasis added].

${ }^{37}$ Draft Set of Rules of Procedure and Evidence for the International Criminal Court, Working Paper Submitted by Australia and the Netherlands 22, 26 July 1996, A/AC.249/L.2.

${ }^{38}$ D. Donat-Cattin, 'Article 68', in Triffterer (n. 13), 1280-1281.

${ }^{39}$ Proposal by New Zealand on Article 43, Non-Paper/WG.4/No.19, 13 August 1997; Amended Proposal by New Zealand on Article 43, Non-Paper/WG.4/No.19/ Rev.1, 13 August 1997.

40 'Report of the Preparatory Committee on the Establishment of an International Criminal Court, Draft Statute and Draft Final Act', A/Conf.183/2/Add.1, 1998, at 82-83 and 129-130.
} 
Discussions at the Rome Conference in relation to Article 68 were framed by a draft proposal of the Canadian delegation. ${ }^{41}$ This draft merged the first three paragraphs of the Preparatory Committee draft into only two. ${ }^{42}$ As a result, the responsibility of the Court as a whole now moved to the beginning of the article, as in the statutory provisions of the ICTY and ICTR. As a second important consequence, the responsibilities of the Prosecutor moved also more prominently to paragraph 1 of Article 68, directly following the responsibilities of the Court as a whole. As a third important consequence, the language in relation to the VWU changed to a less-obligated "may": the Victims and Witnesses Unit "may advise the Prosecutor and the Court on appropriate protective measures, security arrangements, counselling and assistance referred to in article 44, paragraph 4" [emphasis added]. Article 68 therefore emphasized the important role of the Prosecutor in taking protective measures.

The draft article that ultimately became Article 43 also underwent a significant re-wording. This change in wording first appeared on 30 June 1998 in the text of the Conference Coordinator responsible for Articles 43 and $44^{43}$ and was transferred from there to all further drafts $^{44}$ up to the final version of Article 43. According to the amended wording, the VWU "shall provide, in consultation with the Office of the Prosecutor, protective measures and security arrangements, counselling and other appropriate assistance for witnesses, victims who appear before the Court, and for others who are at risk on account of testimony given by such witness" [emphasis added].

${ }^{41}$ Schabas (n. 16), 823.

${ }^{42}$ United Nations Diplomatic Conference of Plenipotentiaries on the Establishment of an International Criminal Court, Proposal Submitted by Canada, Article 68, A/CONF.183/C.1/WGPM/L.58 and A/CONF.183/C.1/WGPM/L.58/Rev.1, 6 July 1998; Report of the Working Group on Procedural Matters, A/CONF.183/C.1/ WGMP/L.2, 24 June 1998.

${ }^{43}$ Committee of the Whole, Coordinator's Text on Articles 43 and 44, A/CONF.183/C.1/L.36, 30 June 1998.

${ }^{44}$ Recommendation of the Coordinator, A/CONF.183/C.1/L.45, 4 July 1998; Drafting Committee, Texts Adopted on First Reading (7 July 1998), A/CONF.183/ DC/R.98, 7 July 1998; Report of the Drafting Committee to the Committee of the Whole, Part 4. Composition and Administration of the Court, A/CONF.183/C.1/ L.67, 13 July 1998. 
From optionally advising the other organs, the role of the VWU in Article 43 was suddenly enhanced to being responsible for carrying out protective measures. The redrafting of Article 43 was now completely inconsistent with the provisions of Article 68. In the recommendations of the Working Group's Coordinator, a footnote demonstrates the awareness of the drafters that the provisions of draft Articles 68 and 44 had to be brought into line. ${ }^{45}$ On 7 July 1998, the Chairman of the Committee of the Whole asked the Chairman of the Drafting Committee to bring the text of draft Article 44 in line with draft Article 68(5) (later Article 68(4)), thereby fully aware that there was a discrepancy. ${ }^{46}$ The adjustment of both articles obviously did not take place.

Also at the Rome Conference, the majority of delegates supported a proposal recommending that the VWU should be placed within Registry. ${ }^{47}$ Some of the States (Slovenia, Finland) stressed that the VWU would be better placed in the Registry because of its "neutrality". 48

In sum, the drafting at the Conference changed the system of responsibilities for protective measures to an incoherent framework: on the one hand, Article 68(1) gave the Prosecutor a decisive role in the field of protective measures, while the VWU was confined to an advisory function; on the other hand, Article 43(6) put the VWU in charge of providing protective measures, in consultation with the OTP. Here lies the starting point of all further confusions about the role of the respective organs. The following section will explore some of the controversies in the early practice of the Court that can traced back to the ambiguity in the drafting of these two provisions.

${ }^{45}$ Recommendation of the Coordinator, A/CONF.183/C.1/L.45, 4 July 1998, footnote 89: "The language of this paragraph should be brought in line with that of article 68, paragraph 5."

${ }^{46}$ Note regarding Articles 37, 43, 44 and 49 contained in the transmittal letter from the Chairman of the Committee of the Whole to the Chairman of the Drafting Committee, 7 July 1998.

${ }^{47}$ Proposal Submitted By the Republic of Congo and Niger, Article 44, A/CONF.183/C.1/L.43, 3 July 1998; Summary records of the meetings of the Committee of the Whole, 2nd meeting, 14 June 1998, and 15th meeting, 24 June 1998, A/CONF.183/SR.2, para. 30 (Trinidad and Tobago); A/CONF.183/C.1/ SR.15, paras. 64 (Belgium), 97 (Slovenia), 100 (Argentina); A/CONF.183/C.1/SR.15, paras. 118 (Thailand), 121 (Trinidad and Tobago), 130 (Finland).

${ }^{48}$ Summary records of the meetings of the Committee of the Whole, 3rd meeting, A/CONF.183/SR.3, 16 June 1998, para. 73 (Costa Rica). 


\section{SOME CONTROVERSIES RELATING TO RESPONSIBILI- TIES FOR THE PROVISION OF PROTECTIVE MEASURES}

\subsection{Admittance into the Witness Protection Programme - Lubanga 2008}

Prior to the scheduled beginning of the Lubanga trial, in early October 2007, the prosecution informed the Chamber that 35 of its 37 trial witnesses "require the protection of the Registry's Victims and Witnesses Unit". ${ }^{49}$ In the view of the Trial Chamber, the prosecution had referred 11 witnesses to the VWU ahead of time, however, "the process for the outstanding 24 witnesses was commenced significantly and unjustifiably late". ${ }^{50}$ As explained in detail in Section 4.3, a protection referral application is an inter-organ procedure, during which the OTP refers a matter to the Registry.

During status conferences on 12 and 13 February 2008, the OTP contended that the VWU was obliged by Article 43(6) to provide protective measures for all witnesses "who are at risk". Whereas the OTP asked that that "all foreseeable risks" should be eliminated, the VWU determined a different threshold, identified as "a high likelihood that the witness will be harmed or killed unless action is taken". ${ }^{51}$

At the same status conference, the VWU revealed "that a fundamental difference of approach had emerged between the prosecution and the Unit during the preceding year that has impeded the progress of this case". ${ }^{52}$ The prosecution and the VWU had previously operated on an agreed upon set of four criteria, which the VWU then "abandoned". 53 The VWU admitted that it had modified the

${ }^{49}$ Prosecutor v. Lubanga (Transcript of Status Conference), ICC-01/04-01/ 06-T-52-ENG (1 October 2007) 27, line 15-20.

${ }^{50}$ Prosecutor v. Lubanga (Decision regarding the Timing and Manner of Disclosure and the Date of Trial), ICC-01/04-01/06-1019 (9 November 2007), para. 20.

${ }^{51}$ Prosecutor v. Lubanga (Transcript of Status Conference), ICC-01/04-01/06-T-74Conf-Exp-ENG (12 February 2008) quoted in Prosecutor v. Lubanga (Decision on Responsibilities for Protective Measures), ICC-01/04-01/06-1311 (24 April 2008), para. 56.

52 Prosecutor v. Lubanga (Transcript of Status Conference), ICC-01/04-01/ 06-T-74-Conf-Exp-ENG (12 February 2008), quoted in Lubanga Decision on Responsibilities for Protective Measures, ibid., para. 35.

${ }^{53}$ Lubanga Decision on Responsibilities for Protective Measures, ibid., para. 34, referring to criticism of the OTP towards VWU. 
approach originally applied, which granted entry into the programme when a certain number of these criteria were met. These criteria were now seen "as no more than one of the available tools" in "an organic and developing area". ${ }^{54}$ Instead, the VWU submitted that its role "was to exercise independent judgment on the applications, as opposed merely to implementing the wishes of the parties". ${ }^{55}$

\subsubsection{Trial Chamber I Decision of 24 April 2008}

The Trial Chamber abstained from any comments on "the respective roles of the VWU and the prosecution (...) in any wider sense". The Chamber stressed that its decision was "fact-specific"; and that it would intervene into the decision-making process of the Registrar only if she would have clearly applied the wrong criteria.

Without further explanation, the Trial Chamber then simply stated that the criticism towards the VWU was "without sustainable foundation". ${ }^{56}$ It complimented the VWU for an assessment on a "fact sensitive rather than a mechanical or formulistic basis". ${ }^{57}$ In terms of the timing of the protection referrals, it qualified the activities of the OTP as "excessively late". ${ }^{58}$ The Trial Chamber further pointed out that the OTP and the VWU "regrettably have been unable to agree on the extent of their respective responsibilities for witnesses who may be at risk of harm". 59

Nevertheless, the Trial Chamber offered the prosecution the option to find its own solutions after a referral application was rejected by the VWU: "It is to be stressed that if the Unit properly assesses and rejects referrals to its protection programme, thereafter it is for the referring party to decide whether to secure any other protective solution, as it considers appropriate". ${ }^{60}$

As a result of this decision, the prosecution was not in a position to disclose in a timely manner the identity and statements of the witnesses whose applications to the programme had been refused. The Trial Chamber saw no other choice than to postpone the

\footnotetext{
${ }^{54}$ Ibid., para. 41.

55 Ibid., para. 42.

56 Ibid., para. 77.

${ }^{57}$ Ibid., 79 and 82.

58 Ibid., para. 81.

59 Ibid., para. 77.

${ }^{60}$ Ibid., para. 80 [emphasis added].
} 
beginning of the trial to the end of June 2008 (from where it was again delayed to early 2009).

The difficulties that arose in this incident had their origin in the contradictory provisions of Articles 43(6) and 68(4). Whereas both parties agreed upon the issue that the VWU administers the Court's witness protection programme (as the protective measure in question), they disagreed on the criteria that determined access to the programme and thereby on the question of who decides on these criteria.

The controversy was further rooted in the two different concepts of the role of the VWU, as outlined in Section II. The OTP, based on Articles 54(3)(f) and 68(1), viewed the referral application to the VWU as a service request, in nature similar to a translation or an IT request. In this view, the prosecution asked the Registry to provide a service that it has no budget and resources to perform itself. ${ }^{61}$ The prosecution relied on Article 54(3)(f) to "take necessary measures, or request that necessary measures be taken, to ensure (...) the protection of any person (...)" ${ }^{62}$ Contrary to that, the VWU has emphasized its neutral role to both prosecution and defence. This neutral role is based on the incorporation of the Unit into the Registry in accordance with Article 43(6).

In its decision, the Trial Chamber stressed the need for a comprehensive inter-organ approach towards all protective measures available. As a result, while the prosecution is responsible for the protection of its witnesses prior to in-court testimony, it needs at the same time to closely coordinate its activities with the VWU. The Trial Chamber viewed the VWU as a neutral unit to both parties that does not automatically have to implement all requests coming from the OTP or the defence. The rationale behind a neutral provision of certain protective measures is the idea that these measures should not be construed as an incentive for the witness to provide evidence in favour of the prosecution's case.

${ }^{61}$ The OTP understands that it "relies where appropriate on the Registry for services". See Corporate Government Statement of the International Criminal Court, as Annex to ASP Committee on Budget and Finance, Report of the Court on measures to increase clarity on the responsibilities of different organs, ICC-ASP/9/ CBF.1/12 (18 March 2010), 11.

${ }^{62}$ Emphasis added. 


\subsection{Preventive Relocation - Katanga 2008}

In the Katanga proceedings, the OTP submitted referral applications for the inclusion of several witnesses into the "International Criminal Court Protection Program" (ICCPP). The prosecution intended to rely on these witnesses for the purpose of the Confirmation Hearing. After the Registrar turned these referral applications down, the OTP, on its own initiative, relocated four witnesses which it deemed at risk due to their interaction with the Court. ${ }^{63}$ To justify the measure of "preventive relocation", the OTP relied on Article 68(1), which, in its view, "gives a special responsibility to the Prosecution to protect its witnesses". 64

\subsubsection{Pre-Trial Chamber I Decision of 21 April 2008}

In its decision, the Pre-Trial Chamber concluded that the Prosecutor has no power to preventively relocate witnesses. ${ }^{65}$ Based on Article 43(6), in view of the Single Judge, the Registrar is responsible for running the ICCPP, and the role of both prosecution and defence is limited to making applications for the inclusion of witnesses into the programme. In relation to protective measures, the judge observed that, by implementing the practice of preventive relocation, the prosecution was "misusing its mandate in order to de facto shift the power to decide on the relocation of a given witness from the Registry to the Prosecution". ${ }^{66}$ Furthermore, when referring to Article 68(1), the Pre-Trial Chamber also concluded that a literal interpretation of the article does not grant the Prosecutor the power to preventively relocate witnesses. ${ }^{67}$ The Pre-Trial Chamber then criticized the VWU for unilaterally changing the criteria for admission into the witness protection programme. ${ }^{68}$

The Pre-Trial Chamber could have left the issue at this point, making preventive relocation a question of specific protective

${ }^{63}$ Prosecutor v. Katanga and Ngudjolo (Prosecution's Submission of Information on the Preventive Relocation of Witnesses 132, 163, 238 and 287), ICC-01/04-01/ 07-374-Conf-Exp. (7 April 2008), p. 3.

${ }^{64}$ Ibid., 6.

${ }^{65}$ Prosecutor v. Katanga and Ngudjolo (Decision on Evidentiary Scope of the Confirmation Hearing, Preventive Relocation and Disclosure under Article 67(2) of the Statute and Rule 77 of the Rules), ICC-01/04-01/07-428-CORR (25 April 2008), para. 23.

${ }^{66}$ Ibid., para. 32.

${ }^{67}$ Ibid., para. 24.

${ }^{68}$ Ibid., para. 49 [emphasis added]. 
measures, for which the Registry is responsible, and not protection in general. However, the argument of the Pre-Trial Chamber became less convincing when it resorted to a "contextual interpretation" of Article 68(1), which led the Single Judge to make findings on the responsibilities of the Prosecutor for protection. It is questionable to limit the prosecution's mandate for protection under Article 68(1) to the following functions:

(i) advising the witnesses as to what they can expect from the Court in terms of protection, as well as the competent organ of the Court for the adoption and implementation of the different protective measures; (ii) requesting the inclusion of witnesses in the ICCPP, as well as providing the Registrar with the necessary information to facilitate the assessment process; and (iii) requesting procedural protective measures such as redactions of identifying information from the Chamber. $^{69}$

The Pre-Trial Chamber could only have come to this conclusion because it limited its contextual interpretation of Article 68(1) to Article 43(6), but did not pay attention to the equally relevant Articles 54(3)(f) and 68(4). ${ }^{70}$

Following its argumentation, the Pre-Trial Chamber decided that "the Prosecution shall immediately put an end to the practice of preventive relocation".71 As a remedial action, the Pre-Trial Chamber initially excluded the use of statements, interview notes and interview transcripts of two witnesses that had been relocated. ${ }^{72}$ As a consequence, the Prosecutor withdrew the charge of sexual slavery that appeared in the arrest warrants for Katanga and Ngudjolo, apparently unable to support the charge without those witnesses. The Registry then agreed to admit the two witnesses into the ICCPP, not out of reconsideration of the original risk assessment but rather due to new security concerns incurred following the Prosecutor's preventive relocations. ${ }^{73}$

\footnotetext{
${ }^{69}$ Ibid., para. 25.

${ }^{70}$ As pointed out by the Prosecution in Prosecutor v. Katanga and Ngudjolo (Prosecution's Document in Support of Appeal Against the Decision on the Evidentiary Scope of the Confirmation Hearing and Preventive Relocation), ICC-01/ 04-01/07-541 (2 June 2008), paras. 26-27.

${ }^{71}$ Katanga Decision on Preventive Relocation (n. 65), para. 54.

72 Ibid., para. 39.

${ }^{73}$ Prosecutor v. Katanga and Ngudjolo (Victims and Witnesses Unit's Considerations on the System of Witness Protection and the Practice of "Preventive Relocation,"), ICC-01/04-01/07-585 (12 June 2008), paras. 39-42. For a concise summary
} 
Read together, the decisions of Trial Chamber I and Pre-Trial Chamber I, both from April 2008, provide rather ambivalent guidance to the question of whether the OTP has the power to implement relocation upon refusal of an application by the VWU. While the Lubanga ruling indicates some discretion for the OTP, the Katanga decision is much stricter. Despite the potentially flexible ruling of Trial Chamber I, the OTP has abstained from further litigating the matter in the Lubanga proceedings. After the Appeals Chamber decision in the Katanga proceedings from November 2008, the OTP has also abstained from unilaterally implementing further measures of relocation.

\subsubsection{Appeals Chamber Decision of 26 November 2008}

The Appeals Chamber undertook an analysis of the drafting of Article 43(6) and came to the conclusion that "the role of VWU in relation to protective measures was (...) not limited to the provision of giving advice alone". ${ }^{74}$ It thereby stressed the double-function of the VWU of providing and recommending protective measures. It is regrettable that the Appeals Chamber, as Pre-Trial Chamber I had in its decision, explored the drafting of only one of the key statutory provisions, but did not look at the drafting history of Articles 54 and 68. In that context, the Appeals Chamber could have further elaborated on the "significant role" that the Prosecutor plays in relation to measures of relocation. ${ }^{75}$

Even based on the analysis as conducted, the Appeals Chamber determined that the "VWU is responsible for specific aspects of witness protection" while the Prosecutor maintains a "more general mandate" in relation to protection matters. ${ }^{76}$ Explicitly, the Appeals Chamber emphasized the need for cooperation between the organs, which it deemed "essential" and of "vital importance" for the success of witness protection. ${ }^{77}$ The "more general mandate" of the OTP

Footnote 73 continued of the preventive relocation episode, see also Human Rights Watch, Courting History. The Landmark International Criminal Court's First Years 171 (2008).

${ }^{74}$ Appeals Chamber Judgement on Preventive Relocation, 26 November 2008 (n. 25), para. 90.

75 Ibid., para. 100.

76 Ibid., para. 98.

77 Ibid., para. 101. The dissenting opinion goes as far as to say that cooperation is envisioned by the provisions of article 43(6) and article 68(4). See Dissenting Opinion of Judges Pikis and Nsereko (26 November 2008), para. 23. 
enables the Prosecutor to take charge of protective measures for its witnesses, prior to testimony in court, with the exceptions as mentioned in the judgment. In cases of disagreement, the Chamber saw itself as the "ultimate arbiter". ${ }^{78}$

In contrast, the dissenting judges put decisive weight on Article 68, which, in their view, "is the main statutory provision definitive of the powers, authority and responsibilities for providing protection to victims and witnesses". ${ }^{79}$ According to the dissenting judges, a decision to grant the Registrar exclusive responsibility to approve and implement protective measures "flies in the face of the unequivocal provisions of article 68(1) and article 54(3)(f)" ${ }^{80}$

Although having a tendency of being one-sided in its analysis, the judgment emphasized the wider OTP mandate for protective measures before in-court testimony, but, at the same time, assigned clearly defined responsibilities for protective measures to the VWU. The latter's responsibilities were extended beyond the inclusion into the protection programme to all protective measures involving the relocation of witnesses. In summary, like the Lubanga decision, the judgment has thereby strengthened the need for a comprehensive inter-organ approach in relation to protective measures.

\section{DEVELOPED PRACTICES}

This section focuses on non-judicial measures of protection, which were developed by the ICC as an innovative tool to cope with the challenges of simultaneously investigating and prosecuting in situations of ongoing conflict or immediate post-conflict. By overcoming some of the initial difficulties as previously described, the Court as a whole has managed to achieve substantive results in the development of satisfactory protective tools. One positive - and immediately obvious - indicator for the effectiveness of the protective measures of the Court is the fact that, at the time of writing this paper, none of the more than 500 witnesses seems to have suffered serious harm due to his or her interaction with the Court. ${ }^{81}$ As a significant achievement, in March 2011, the Prosecutor and the Registrar

\footnotetext{
${ }^{78}$ Appeals Chamber Judgement on Preventive Relocation (26 November 2008), para. 97.

${ }^{79}$ Appeals Chamber Judgement on Preventive Relocation, Dissenting Opinion of Judges Pikis and Nsereko (26 November 2008) (n. 20), para. 15.

${ }^{80}$ Ibid., para. 7.

${ }^{81}$ Mahony (n. 5), 16.
} 
concluded a Joint Protocol on the Mandate, Standards and Procedure for Protection, which clarifies and institutionalizes the relationship between both organs in the field of protective measures. ${ }^{82}$

At various times before the Chambers, the VWU has outlined its approach to protective measures as follows:

The very foundation of the Court's protection system lies on the application of good practises by any representative of the Court who interacts with witnesses. These practices are aimed at hiding a witness's interaction with the Court from the community where the witness resides, from potential threats and the public. These practices are enhanced by an Initial Response System (IRS) which enables the Court to extract witnesses who are afraid of being immediately targeted or who have been targeted to a safe location in the field. A protective measure of last resort is the entry to the ICCPP and subsequent relocation of the witness and his or her close relations away from the source of the threat. ${ }^{83}$

Beyond these general principles, more in-depth public information in relation to the protective measures of the Court is scarce. In particular, the VWU does not specify or provide examples of what it considers to be "good practices" beyond the fact that "these are based on the premise that prevention is the best protection". ${ }^{84} \mathrm{In}$ view of the OTP, good practices are appropriate to avoid creating or exacerbating risks, but have limited utility in reducing existing risks. ${ }^{85}$ They are "always necessary", but "may not always be sufficient". 86

In its Regulations, the OTP has committed itself to develop an "Area-Specific Threat and Risk Assessment" for each area of operation related to an investigation; to ensure direct and secure contact

${ }^{82}$ The Protocol is not public, but reference is made in court filings. See, for example, Prosecutor v. Muthaura et al. (Prosecution's Response to "Defence Request for Variation of Decision on Summons or in the Alternative Request for Leave to Appeal"), ICC-01/09-02/11-59 (15 April 2011), para. 8.

${ }^{83}$ Prosecutor v. Katanga and Ngudjolo (Victims and Witnesses Unit's Considerations on the System of Witness Protection and the Practice of "Preventive Relocation"), ICC-01/04-01/07-585 (12 June 2008), paras. 9-10; see also Arbia (n. 4); Summary Report on the Seminar on Protection of Victims and Witnesses Appearing Before the International Criminal Court (24 November 2010).

${ }^{84}$ Summary Report on the Round Table on the Protection of Victims and Witnesses Appearing Before the International Criminal Court (29-30 January 2009).

${ }^{85}$ Prosecutor v. Katanga and Ngudjolo (Prosecution's Response to "Victims and Witnesses Unit's considerations on the system of witness protection and the practice of 'preventive relocation"'), ICC-01/04-01/07-664 (7 July 2008), footnote 70.

${ }^{86}$ Prosecutor v. Katanga and Ngudjolo (Prosecution's Document in Support of Appeal against the Decision on the Evidentiary Scope of the Confirmation Hearing and Preventive Relocation), ICC-01/04-01/07-541 (2 June 2008), para. 19. 
with witnesses in adherence to good practices; and to regularly update general and individual security risk assessments. ${ }^{87}$ The OTP further obliges itself to implement protective measures that are adequate and necessary given the circumstances of each case. ${ }^{88}$

\subsection{Initial Response System (IRS)}

In the words of the ICC Registrar, the IRS is "a 24/7 emergency response system which enables the Court to extract to a safe location in the field witnesses who are afraid of being imminently targeted or who have in fact been targeted". ${ }^{89}$ A call to the "emergency hotline" activates a network of local partners with the capacity to intervene and extract an individual to a safe location in case of an urgent threat. ${ }^{90}$ The threat is subsequently assessed by VWU protection officers in order to determine if further protective measures are required.

An IRS functions only in defined geographic areas where multiple witnesses are residing. Local partners implementing the IRS are well remunerated personnel from the security sector or have previous security sector experience. ${ }^{91}$ They do not know about the identities of potential users of the IRS hotline; their involvement is for the most part limited to follow a pre-established protocol to bring a threatened individual to a safe location. ${ }^{92}$ As an example, in Uganda, the domestic police force assists with the implementation of the IRS. Effective maintenance of the system requires training of the local police, regular contact with local authorities and frequent testing of

${ }^{87}$ Regulations of the Office of the Prosecutor, Regulation 44 and Regulation 45(c) and (e).

${ }^{88}$ Regulations of the Office of the Prosecutor, Regulation 46.

${ }^{89}$ Arbia (n. 4), 522; see also Summary Report on the Round Table on the Protection of Victims and Witnesses Appearing Before the International Criminal Court (29-30 January 2009); Regulations of the Registry, Regulation 95 (Protection arrangements).

${ }^{90}$ Human Rights Watch, Courting History. The Landmark International Criminal Court's First Years (2008) 152.

${ }^{91}$ Mahony (n. 5), 41.

92 Human Rights Watch, Courting History (n. 90), 153; all information is based on interviews of Human Rights Watch with ICC Staff in May 2007 and March 2008; Mahony (n. 5), 36-37. 
its efficacy and responsiveness. ${ }^{93}$ The IRS is managed and financed by the VWU. ${ }^{94}$

Over the years, judges have accepted that the IRS is one of the protective measures genuinely offered by the Court. In evaluating the protective measures available to individuals, in their decisions judges now make reference to the question of whether a person has access to the IRS ${ }^{95}$; or they might refer to the IRS in relation to other available protective measures. $^{96}$

An IRS has financial implications and is therefore also of concern to the States Parties. When the Court entered the trial stage of its first proceedings, in 2007, the ASP Bureau foresaw "the increase in expenditure to provide satisfactory protection for witnesses. This is particularly relevant for the implementation and maintenance of the initial response systems for witnesses under threat". ${ }^{97}$ In the budget

${ }^{93}$ Assembly of States Parties, Report of the Court on the Kampala Field Office: activities, challenges and review of staffing levels; and on memoranda of understanding with situation countries, ICC-ASP/9/11 (30 July 2010), 2.

${ }^{94}$ Assembly of States Parties, Proposed Programme Budget for 2011 of the International Criminal Court, ICC-ASP/9/10 (2 August 2010), 115; Assembly of States Parties, Proposed Programme Budget for 2010 of the International Criminal Court, ICC-ASP8/10 (30 July 2009), 109; see also the reference to acquisition of new vehicles for the Initial Response Systems in Assembly of States Parties, Report of the Court on Capital Investment Replacements, ASP/8/27 (29 October 2009), 3, Table 1. One of the ongoing activities of VWU is the development of IRS. See job posting for a VWU Operations and Field Coordination Assistant, which includes, as one of the duties and responsibilities, assistance "with the development of Initial Response Systems and other local protection and security arrangements for victims and witnesses in the field". See http://www.icc-Cpi.int/Menus/Go?id=db159d3a-894041a3-985d-a6fff384dab1\&lan = en-GB.

${ }^{95}$ See for example, Prosecutor v. Lubanga (Prosecution's Request for Protective Measures for one Prosecution Witness), ICC-01/04-01/06-1643 (23 January 2009), 3; Prosecutor v. Katanga and Ngudjolo (Decision on the "Prosecution's Request for Non-Disclosure of the Identity of Eight Individuals providing Rule 77 Information" of 5 December 2008 and "Prosecution's Request for Non-Disclosure of Information in One Witness Statement Containing Rule 77 Information" of 12 March 2009), ICC-01/04-01/07-1980-Anx2 (24 June 2009), para. 14.

${ }^{96}$ Prosecutor v. Katanga and Ngudjolo (Decision on the Prosecutor's Application to Redact Information under Article 67(2) of the Statute or Rule 77 of the Rules of Procedure and Evidence), ICC-01/04-01/07-1101-tENG (4 May 2009), para. 43.

${ }^{97}$ Assembly of States Parties, Report of the Bureau on Cooperation, ASP/6/21 (19 October 2007) 12. 
for 2009, the "expansion of initial response systems in the field" was a relevant factor. ${ }^{98}$

\subsection{Security Risk Assessment (SRA) and Individual Risk Assessment (IRA)}

In accordance with its Regulations quoted above, the OTP conducts continuing risk assessments, first of all on a more general level, for instance in relation to the situation in the DRC or the Central African Republic. ${ }^{99}$ The VWU cooperates in these assessments preceding OTP investigation missions and identifying protection and support needs and measures to be taken in connection with investigations. ${ }^{100}$

The OTP also conducts individual risk assessments for each witness. ${ }^{101}$ Next to biographical information, the IRA contains information, inter alia, about all prior security related incidents or threats that have already occurred with respect to the individual; conditions under which the individual might be exposed to risks and an overview of those risks; and specific protective measures currently in place. This ongoing risk assessment, in the words of the prosecution, "will allow us to determine if such measures will be sufficient once the names of the witnesses have been disclosed". ${ }^{102}$

Court filings demonstrate how IRAs are used in front of Trial Chambers and Pre-Trial Chambers and how the OTP and the VWU presently cooperate in this domain. In the Bemba proceedings, the PreTrial Chamber made it clear to the OTP and the Registry that it expected maximum cooperation between them in the area of witness protection:

The Chamber wishes to emphasize that cooperation amongst the organs of the Court is crucial for ensuring the efficient and expeditious conduct of the proceedings with full respect to the rights of the Defence and with due regard for the protection of victims and witnesses. ${ }^{103}$

\footnotetext{
${ }^{98}$ Assembly of States Parties, Proposed Programme Budget for 2009 of the International Criminal Court, ASP/7/9 (29 July 2008), 7-8.

99 Prosecutor v. Bemba (Prosecutor's Decision concerning Prosecutor's Proposal for Redactions), ICC-01/05-01/08-58Red (31 July 2008), para. 10.

${ }^{100}$ Human Rights Watch, Courting History (n. 90), 152.

101 Bemba Prosecutor's Decision concerning Prosecutor's Proposal for Redactions (n. 99), para. 10.

102 Ibid., para. 11.

103 Prosecutor v. Bemba (Decision on the Security Situation of Witnesses), ICC-01/ 05-01/08-202 (3 November 2008), para. 20.
} 
In early September 2008, the prosecution shared an SRA and 14 IRAs with the VWU. ${ }^{104}$ An additional IRA was submitted in October 2008. ${ }^{105}$ All IRAs were regularly updated and submitted to the Chamber upon request. ${ }^{106}$

In November 2008, Pre-Trial Chamber III ordered an updated "risk assessment report" with regard to 11 witnesses presented by the prosecution. ${ }^{107}$ In relation to some of those witnesses, the Pre-Trial Chamber was not satisfied with the information provided by the prosecution as it was "lacking substantial factual elements to properly assess the security situation of those witnesses". ${ }^{108}$ Therefore, the Chamber requested "further clarifications on the present security situation". ${ }^{109}$ The OTP was ordered to contact the witnesses immediately, consult with the VWU and then report back to the Chamber. Despite the expressed dissatisfaction with some of the submitted IRAs, the Pre-Trial Chamber decision implicitly showed that the judges had accepted the IRA as a proper tool to evaluate the security situation of a witness. After consulting with the VWU the day following the Pre-Trial Chamber decision, the OTP reported back to the Chamber that, in its view, the security situation of the witnesses had not undergone any significant changes. ${ }^{110}$

The Abu Garda proceedings, relating to the Darfur situation, provide another illustration as to when IRAs are used as an established tool to evaluate protective measures. As the prosecution had indicated that it had carried out a "security risk assessment" of all witnesses, the Single Judge asked to submit an equivalent report, so that she could properly assess the requests for redactions. The Single

${ }^{104}$ Prosecutor v. Bemba (Prosecutor's Position regarding Disclosure of Additional Witnesses for Referral to VWU in Response to Pre-Trial Chamber III's Order dated July 23, 2008), ICC-01/05-01/08-91 (4 September 2008), para. 11.

105 Prosecutor v. Bemba (Prosecution's Application for Proposed Redactions Pursuant to Rules 81(2) and 81(4) of the Rules of Procedure and Evidence), ICC-01/ 05-01/08-164 (17 October 2008), para. 23.

106 Prosecutor v. Bemba (Prosecution's Amended Application for Proposed Redactions Pursuant to Rules 81(2) and 81(4)), ICC-01/05-01/08-114 (22 September 2008), para. 24.

${ }^{107}$ Bemba Decision on the Security Situation of Witnesses (n. 103), para. 6.

108 Ibid., para. 13.

109 Ibid., para. 19.

${ }^{110}$ Prosecutor v. Bemba (Prosecution's Submission of Additional Information Pursuant to "Decision on the Security Situation of Witnesses"), ICC-01/05-01/08209-Red (5 November 2008), para. 8. 
Judge further gave the VWU a period of 10 days to comment on the OTP's report, thereby making sure that the IRAs were shared among the organs of the Court. ${ }^{11}$ The OTP submitted 16 IRAs in the requested time frame. ${ }^{112}$ The decisions of the Single Judge in relation to redactions were taken after she had reviewed the IRAs and heard the (non-public) views of the VWU. ${ }^{113}$

\subsection{The Court's Witness Protection Programme (ICCPP)}

In the statutory rules of the ICC, Rule 16(4) makes the only direct reference to the witness protection programme of the Court. ${ }^{114}$ According to this rule, agreements on relocation of victims and witnesses may be negotiated with states by the Registrar on behalf of the Court. Rule 16(4) thereby refers to two important features of the ICCPP: the programme is administered by the Registrar and its capacities are based on the cooperation of States Parties.

The mechanisms for the witness protection programme are further elaborated on in the Regulations of the Registry. Regulation 96 provides, inter alia, that "an application for inclusion in the protection programme may be filed by the Prosecutor or by counsel". ${ }^{115}$ In essence, a referral application for acceptance into the ICCPP becomes an inter-organ procedure. The prosecution has no control over the timing of the decision-making process within the Registry. ${ }^{116}$

${ }^{111}$ Prosecutor v. Abu Garda (Decision Ordering the Prosecutor to Submit a Report on Witness' Security Risk Assessment), ICC-02/05-02/09-41 (30 July 2009), 5.

112 Prosecutor v. Abu Garda (Prosecutor's Report on Witnesses' Security Risk Assessment with Confidential, Ex Parte, Prosecution and VWU only Annex A), ICC-02/05-02/09-43 (4 August 2009).

113 Prosecutor v. Abu Garda (First Decision on the Prosecution's Requests for Redactions, issued on 14 August 2009), ICC-02/05-02/09-58 (20 August 2009).

${ }^{114}$ At the Special Tribunal for Lebanon, a protection programme is defined for the first time within the system of an international criminal court; see Special Tribunal for Lebanon - Rules of Procedure and Evidence, Article 166, as amended on 30 October 2009: "The Registrar shall establish a protection programme within the Victims and Witnesses Unit for the purpose of protecting individuals through relocation to Third States. The Registrar shall take all necessary measures to arrange relocation to Third States of individuals and their close relations who, following the determination of the Registrar, are at risk of imminent serious harm or death as a result of their interaction with the Tribunal. All procedures and administrative functions in relation to the Protection Programme shall remain confidential."

115 Regulations of the Registry, Regulation 96.

${ }^{116}$ At a status conference in December 2007, the Prosecution was "not in a position to provide (...) information on how much time it will take the Victims and 
The VWU conducts "a careful and independent evaluation and assessment of the information provided", which includes an extensive interview of the witness and the family members as well as an analysis of other information available to the VWU. ${ }^{117}$ The VWU has claimed that, "given the difficult situations in the field, the VWU's assessment necessarily takes some time". ${ }^{118}$ The assessment process is lengthy; in 2008 it became evident that it would take an average of at least $2-3$ months. ${ }^{119}$ One of the reasons for the long processing time is what Human Rights Watch has qualified as "inadequate resources" 120 of the VWU. In 2008, the VWU employed 38 permanent staff (including 13 psychosocial personnel). Considering the wide range of situations and threats, the number of staff dealing with protection issues appears to be small compared to ICTR and ICTY, which employed 29 and 23 personnel in 1999 respectively. ${ }^{121}$ Human Rights Watch has therefore recommended that "particular attention should be paid to increasing the staff levels within the VWU to address the protection and support needs of victims". ${ }^{122}$

In its Court filings, the VWU has further elaborated on its views of the ICCPP. It considers the ICCPP a "protective measure of last resort", as "it significantly impacts and disrupts the life of the individual". ${ }^{123}$ As a key requirement, the VWU "can only recommend participation in the ICCPP (...) if the threshold in relation to the level

Footnote 116 continued

Witnesses Unit to assess the referrals and, where applicable, to implement the protective measures". See Prosecutor v. Lubanga (Transcript of Status Conference), ICC-01/04-01/06-T-52-ENG (1 October 2007), 28, line 4-11.

117 Prosecutor v. Bemba (Victims and Witnesses Unit's Observations on the Protection Measures Available in Relation to the Individuals Concerned by the Prosecutor's Proposal for Redaction), ICC-01/05-01/08-72-Red (18 August 2008), para. 25.

${ }^{118}$ M. Dubuisson, A. Bertrand and N. Schauder, 'Contribution of the Registry to Greater Respect for the Principles of Fairness and Expeditious Proceedings before the International Criminal Court' in Stahn and Sluiter (n. 4), 574.

119 Prosecutor v. Katanga and Ngudjolo (Decision on Evidentiary Scope of the Confirmation Hearing, Preventive Relocation and Disclosure under Article 67(2) of the Statute and Rule 77 of the Rules, Corrigendum), ICC-01/04-01/07-428-Corr (25 April 2008), para. 61.

${ }^{120}$ Human Rights Watch, Courting History (n. 90), 150.

${ }^{121}$ Mahony (n. 5); Human Rights Watch, Courting History (n. 90), 151.

${ }^{122}$ Human Rights Watch, Courting History (n. 90), 176.

${ }^{123}$ Arbia (n. 5), 522. 
of risk has been met". ${ }^{124}$ In the ICC context, the precise content of all criteria relevant for the admission into the witness protection programme remains confidential ${ }^{125}$; the criteria are, as such, redacted from the public versions of the relevant court filings. The ICTY is less secretive about the fact that relevant and essential evidence, a real threat and suitability for the programme are the key criteria for admittance into the Tribunal's programme. ${ }^{126}$

Since 2008, both the OTP and the Registry have made a dedicated effort to consult each other as early as possible on the situation of individual witnesses. The OTP has committed itself to share much earlier the scope of its investigations with the VWU. In the case of referral applications, the VWU is therefore less likely to be confronted with the case of an unknown individual in an undefined situational context, but does know about the overall security situation of the investigation earlier on and can therefore better assess the individual security situation.

More pragmatically, the disagreements between organs also reveal general weaknesses in the overall protection scheme of the Court. Naturally, the OTP is interested in providing protection measures to its witnesses; otherwise it might be "unable to bring critical evidence to prove charges at trial". ${ }^{127}$ For witnesses, it is more often than not difficult to understand why the application process takes such a long time; and why different organs of the Court, in a seemingly repetitive way, conduct assessments on similar issues and ask the very same questions. This is one of the reasons why the OTP has tried to rely more on non-witness-related evidence. ${ }^{128}$

The VWU is confronted with capacity deficits in several ways. Apart from the above-mentioned resource limitations, the VWU has only a limited number of slots in the ICCPP available, as it relies on

${ }^{124}$ Prosecutor v. Bemba (Victims and Witnesses Unit's Observations on the Protection Measures Available in Relation to the Individuals Concerned by the Prosecutor's Proposal for Redaction), ICC-01/05-01/08-72-Red (18 August 2008), para. 8.

${ }^{125}$ Human Rights Watch, Courting History (n. 90), 170.

${ }^{126}$ ICTY Manual on Developed Practices. Developed in Conjunction with UNICRI as Part of the Project to Preserve the Legacy of the ICTY (2009) 202.

${ }^{127}$ Prosecutor v. Katanga and Ngudjolo (Prosecution's Document in Support of Appeal against the Decision on the Evidentiary Scope of the Confirmation Hearing and Preventive Relocation), ICC-01/04-01/07-541 (2 June 2008), para. 39.

${ }^{128}$ For the relevance of financial investigations in this context, see M. de Smedt, Head of the Investigations Division, The Role of Companies in Conflicts within the Jurisdiction of the Court, at www.icc-cpi.int/NR/rdonlyres/67FC99ID-5223-475EA76E-73DBA6D7B61/282612/TheRoleofCompanieswithintheCourtsJuris.pdf. 
support from States Parties and other international organizations. The Assembly of States Parties has repeatedly made appeals to States Parties to enter into agreements with the Court on the relocation of witnesses. ${ }^{129}$ From the 210 notes-verbales sent to the States Parties requesting cooperation and assistance in reaching relocation agreements, the Court received only 31 responses. Out of those, 10 States Parties signed a "framework agreement", while two others entered an ad hoc agreement on specific cases. ${ }^{130}$ The total rate of successful relocations is still not more than $40 \%{ }^{131}$

Since 2009, the Registrar has also developed a "Special Fund Model", by which member states can donate to a Special Fund for Relocations to relocate witnesses in third countries "through a costneutral arrangement". ${ }^{132}$ Donations can be undertaken by way of earmarking them for specific states. This model differentiates between a donor state and a host state. A state party can thereby, as donor state, donate funds to assist relocating a witness to a host state, without hosting the witness himself/herself, and vice versa. ${ }^{133}$

As admittance to the ICCPP is both cost-intensive and intrusive to the witnesses' life, discussions have been ongoing about alternative protective measures. The Court has reacted to previous criticism "to adapt the court's protection programs to the diversity of existing protection needs". ${ }^{134}$ Measures that have been suggested and implemented in this context include the use of safe houses, increased police patrolling, closed protection for governmental officials,

${ }^{129}$ Assembly of States Parties Report of the Bureau on Cooperation, ICC-ASP/6/ 21 (19 October 2007), para. 47; Assembly of States Parties, Report on the Activities of the Court, ICC-ASP/7/25 (29 October 2008), para. 80.

${ }^{130}$ Assembly of States Parties, Report of the Bureau on Cooperation, ICC-ASP/8/ 44 (15 November 2009), para 91.

${ }^{131}$ Review Conference to the Rome Statute, Report of the Court on Cooperation: Update, RC/2, 11 May 2010, para. 19.

132 Arbia (n. 4), 523; Summary Report on the Seminar on Protection of Victims and Witnesses Appearing Before the International Criminal Court (24 November 2010) 6; Assembly of States Parties, Report of the Bureau on Cooperation, ICCASP/8/44 (15 November 2009), para. 93.

${ }^{133}$ During the VWU symposium in November 2010, the Special Fund Model was criticized, as it would prevent host states from effectively integrating protected persons into their societies, considering that they would not have to bear any financial burden. See for the comments of the Belgium representative Summary Report on the Seminar on Protection of Victims and Witnesses Appearing Before the International Criminal Court (24 November 2010) 6.

${ }^{134}$ Human Rights Watch, Courting History (n. 90), 174. 
enhanced surveillance of witnesses' homes, or the investigation of security-related incidents by national authorities. ${ }^{135}$ In the Central African Republic situation, the OTP and the VWU have set up a "neighbourhood watch", which is a form of local system of civilian guards that is supposed to patrol in areas where a high density of witnesses is located. The UN High Commissioner for Refugees (UNHCR) has used "evaluation platforms", installed in partner countries where witnesses as refugees may remain for some time before being sheltered in a refugee programme in another country. ${ }^{136}$ The OTP and the VWU have also worked on an "assisted move" scheme, supporting a witness who has not been exposed to an imminent, lifethreatening incident to move with his family to a third country and providing him with support for a limited period of time, so that he can settle in his new location and eventually becomes self-sustainable.

\section{CONCLUSION}

This article undertakes a three-step analysis of the system of protective measures at the ICC. First, it has analyzed the existing legal framework, and has concluded that this framework results in divided, even contradictory internal responsibilities for protective measures (Section II). Subsequently, it has followed how this framework has translated itself into the early practice of the ICC by closely examining two case studies that are based on inherent tensions between Article 43(6) and Article 68(1) (Section III); and by describing how the Court has undertaken significant steps to overcome some of the difficulties by developing established practices for protective measures (Section IV).

As a third step, it recommends implementing a model for protective measures that is based on two key elements: (1) a comprehensive inter-organ approach, translated into practice as a maximum of cooperation, coordination and information exchange; and (2) clearly defined lead responsibilities for specific court organs. The model is inherent in the existing jurisprudence, as analyzed in this paper. It translates the statutory compromise about protective

${ }^{135}$ Summary Report on the Round Table on the Protection of Victims and Witnesses Appearing Before the International Criminal Court (29-30 January 2009) 3; Summary Report on the Seminar on Protection of Victims and Witnesses Appearing Before the International Criminal Court (24 November 2010) 3.

${ }^{136}$ Summary Report on the Seminar on Protection of Victims and Witnesses Appearing Before the International Criminal Court (24 November 2010) 3. 
measures into the practical work of the Court, but has so far gone largely unnoticed in the discussions, both inside and outside of the Court.

\subsection{Comprehensive Inter-Organ Approach}

The relevant jurisprudence, focusing on the particular protective measure of relocation (see Section III), has emphasized the need to evaluate protective measures comprehensively between organs. In this context, relocation is just one option within the wide range of protective measures available to the Court and can only be assessed in close relation with these other protective measures. The current jurisprudence stresses this interdependency. It emphasizes that only after a comprehensive inter-organ risk assessment is conducted can appropriate protective measures be recommended which are then implemented by the organ that is in charge of executing that measure.

In the case study from the Lubanga proceedings (see Section 3.1), the OTP and the Registry were unable to agree on the appropriate risk assessment and therefore also on the appropriate protective measures. The judges concluded that acceptance into the ICCPP was not the appropriate protective measure for most of the witnesses concerned. In the case study from the Katanga proceedings (see Section 3.2) the Appeals Chamber decided that responsibility for any form of relocation, beyond the mere inclusion into the ICCPP, remains in the hands of the VWU. An analysis of the dissenting opinions of this decision demonstrates that one could have argued the responsibility for relocation differently, relying more on Article 68 than on Article 43 of the Statute. The Lubanga Trial Chamber decision of April 2008 further suggested that the OTP, similar to the practice at ICTY, has at least some discretion in implementing relocations. The overarching motivation behind the existing jurisprudence, however, is to acknowledge a significant role for the prosecution and to give the VWU certain clearly defined areas of providing protective measures at the same time, thereby translating the statutory compromise into an intensified need for inter-organ cooperation, coordination and information exchange.

\subsection{Phased Lead Responsibilities}

In addition to an inter-organ system of protective measures, it is recommended, as a second key characteristic, to establish clear 
guidance on which actor has the lead responsibility for a specific protective measure at a specific time. In this context, a model of phased lead responsibilities is suggested. While the focus of this paper has been the phase prior to in-court testimony (phase 2 below), the four following distinct phases of a court case can be distinguished.

\subsubsection{During the Investigation of a Situation - Phase $1^{137}$}

In the early phases of an investigation, before deciding on a case against a particular suspect, all witnesses are potential witnesses, ${ }^{138}$ i.e. no selection has been made if the prosecution intends to rely on an individual in any future proceedings. In this period, the OTP enjoys broad discretionary powers.

\subsubsection{Prior to In-Court Testimony - Phase $2^{139}$}

Prior to a confirmation hearing, the prosecution selects the witnesses relevant to its case. A decision on the evidentiary value of a particular witness statement for the overall case of the prosecution can only be taken by the OTP.

In light of the disclosure obligation, the OTP, in consultation with the VWU, conducts or updates its risk assessments. This update can lead to different potential scenarios. The OTP might come to the conclusion that there is no need for additional protective measures. ${ }^{140}$ The OTP can also reach the conclusion that any of its own protective measures will mitigate the identified risk to the witness after disclosure. ${ }^{141}$ As a third option, the prosecution may apply for judicial measures of witness protection. In doing so, the OTP has to assess if a redacted or summarized witness statement will be able to meet the

${ }^{137}$ That is, from the initiation of an investigation until the initial proceedings before the Court.

138 The question of protection obligation towards screened individuals and their immediate family members as well as sources will have to stay outside of the scope of this article.

139 That is, from disclosure prior to confirmation hearing until immediately before the in-court testimony of a witness.

${ }^{140}$ This could, for instance, be the case for a witness living in an area where neither the suspect nor his supporters have any capacity to harm the witness. The identity and statement of the witness can therefore be disclosed to the defence.

${ }^{141}$ For example, in case of a government official (i.e. a military official), the OTP could request the relevant government authorities to transfer the witness to a new assignment into an area, where he is out of reach of the capacities of the suspect or any other source of threat, after identity and statement are disclosed. 
required evidentiary threshold for the confirmation of charges, ${ }^{142}$ acknowledging that this type of disclosure assigns less probative value to the evidence. ${ }^{143}$

The OTP can also come to the conclusion that a referral application for admittance into the ICCPP is the appropriate protective measure. Once a witness is accepted into the ICCPP, the VWU assumes lead responsibility for the protection. Previous inter-organ differences were rooted in two different concepts about the role of the VWU as described in this article. While the OTP perceived the unit in essence as a service provider, the VWU insisted that its neutral role, serving both parties, included the authority to have decisive powers on referral applications. The Katanga Appeals Chamber decision from November 2008 emphasized the neutral role of the VWU (see Section 3.2). The Lubanga Trial Chamber decision from April 2008 has confirmed that the VWU applied the appropriate admissibility criteria for the programme and that OTP took a too broad approach when aiming at referring witnesses in order to prevent all foreseeable risks (see Section 3.1).

\subsubsection{During In-Court Testimony - Phase 3}

During witness testimony in court, the VWU has lead responsibility for protective measures. ${ }^{144}$ This is in line with the neutral role of the Registry serving witnesses during testimony when they are "the property neither of the Prosecution not of the Defence, and that they should therefore not be considered as witnesses of either party, but as witnesses to the Court". ${ }^{145}$ The Registry has committed itself to develop and implement policies and procedures to enable witnesses to testify "in safety". ${ }^{146}$ These procedures include arrangements for the

${ }^{142}$ Article 61(7), "whether there is sufficient evidence to establish substantial grounds to believe".

${ }^{143}$ Prosecutor v. Lubanga (Decision Concerning the Prosecution Proposed Summary Evidence), ICC-01/04-01/06-517 (5 October 2006), 4 and 6.

${ }^{144}$ See for a description of some of the tasks Human Rights Watch, Courting History (n. 90), 156-158.

${ }^{145}$ Prosecutor v. Lubanga (Decision on Practices of Witness Familiarization and Witness Proofing), ICC-01/04-01/06-679 (8 November 2006), para 26.

${ }^{146}$ Regulations of the Registry, Regulation 79(1). 
witness to travel to the Court, his/her accommodation during testimony and allowances that he/she is paid for the time during his testimony. ${ }^{147}$ In accordance with these regulations, the VWU has developed an extensive protocol to bring witnesses to The Hague and assisting them during that stay. ${ }^{148}$

\subsubsection{After In-court Testimony - Phase 4}

A detailed discussion of the question which organ has lead responsibility for a witness after testimony will have to stay outside the scope of this article. It is suggested that the system of pre-testimony responsibilities is maintained and that therefore the OTP has the lead responsibility for the majority of its witnesses, monitoring the return to their place of residence and during an agreed upon following time thereafter. As a special group, witnesses within the ICCPP are monitored by the VWU. The aim for this limited number of witnesses is to completely integrate them into the society of the host state. ${ }^{149}$ In more general terms, it remains essential that the overall risk assessment is continued, so that fluctuations in risks can be detected in time. ${ }^{150}$

\subsubsection{Further Distribution of Responsibilities}

This paper has focused on the responsibilities for protective measures in the pre-testimony phase. While the OTP has lead responsibility for these measures in relation to its witnesses, this responsibility reaches its limitations in the following situations:

- Judicial measures of witness protection, both for limitations of disclosure and for in-court protective measures, can only be authorized by the relevant Chambers.

\footnotetext{
${ }^{147}$ Regulations of the Registry, Regulations 81-86.

${ }^{148}$ The Protocol is not public; in part, it is referred to in Prosecutor v. Lubanga (Decision Regarding the Protocol on the Practices to be Used to Prepare Witnesses for Trial), ICC-01/04-01/06-1351 (23 May 2008).

${ }^{149}$ Summary Report on the Seminar on Protection of Victims and Witnesses Appearing Before the International Criminal Court (24 November 2010), 2. One issue for the ad hoc Tribunals will be how they can monitor the post-trial situation of relocated witnesses once the tribunals have ceased to exist. The exit strategy of the SCSL suggests that a monitoring residual mechanism will be established for relocated witnesses.
}

${ }^{150}$ Mahony (n. 5), 53. 
- Chambers also make a decision when the protective needs of witnesses have to be balanced against the fair trial rights of the accused. ${ }^{151}$

- If specific disagreements between the OTP and the Registry cannot be solved, they need to be litigated in front of the Chambers for a decision.

- The VWU takes charge of protective measures for the limited number of witnesses who have been accepted into the ICCPP.

In sum, various attempts have been made within the Court to try to develop the ICC into a more efficient, less bureaucratic institution. Witness protection measures have been one focus of these attempts. The developed practices, including the adoption of the Joint Protocol, have already increased clarity and efficiency. This article argues that these efforts should appropriately recognize the model of a comprehensive inter-organ approach and phased lead responsibilities for protective measures. By identifying and recommending the model, this article understands itself to contribute to ongoing initiatives aiming at improved efficiency in the functioning of the Court.

Open Access This article is distributed under the terms of the Creative Commons Attribution License which permits any use, distribution, and reproduction in any medium, provided the original author(s) and the source are credited.

${ }^{151}$ As an example, see the decision of the Appeals Chamber on the issue of the disclosure of identity of Intermediary 143: Prosecutor v. Lubanga (Judgement on the Appeal of the Prosecutor Against the Decision of Trial Chamber I of 8 July 2010 entitled "Decision on the Prosecution's Urgent Request for Variation of the TimeLimit to Disclose the Identity of Intermediary 143 or Alternatively to Stay Proceedings Pending Further Consultations with the VWU"), ICC-01/04-01/06-2582 (8 October 2010) especially paras. 48-54. 